National Marine

Fisheries Service

Fishery Bulletin

Spencer F. Baird

NOAA

$\approx$ established in $1881 \kappa$

First U S Commissioner of Fisheries and founder of Fishery Bulletin

\begin{abstract}
The blue shark (Prionace glauca) in the North Atlantic Ocean is caught in large numbers in commercial fisheries and faces the possibility of overfishing. Reproductive parameters, such as size and age at maturity, are important descriptors of life history characteristics used for understanding and managing marine organisms but have not been evaluated for the western North Atlantic Ocean since 1979. To address this gap in knowledge, we used samples from 369 female and 488 male blue sharks collected during 1971-2016 and examined whether maturity parameters have changed over time. We compared sex-specific fork length (FL) $\left(L_{50}\right)$ and weight $\left(W_{50}\right)$ at median maturity between 2 time periods (1971-1977 and 2003-2016). No evidence of change in either $L_{50}$ or $W_{50}$ was observed for females. Males had a statistically significant increase in both parameters; however, this increase was likely the result of differences in sample size range between the time periods. Thus, all data from 1971 through 2016 were combined to obtain new estimates of age and size at $50 \%$ maturity for both sexes. The $L_{50}$ and $W_{50}$ are $192.5 \mathrm{~cm} \mathrm{FL}$ and $49.5 \mathrm{~kg}$ for male blue sharks and $190.9 \mathrm{~cm} \mathrm{FL}$ and $50.1 \mathrm{~kg}$ for female blue sharks. These updated $L_{50}$ and $W_{50}$ increase reliability of data inputs for fisheries management.
\end{abstract}

Manuscript submitted 14 September 2021 Manuscript accepted 16 December 2021. Fish. Bull. 120:26-38 (2021).

Online publication date: 5 January 2022. doi: 10.7755/FB.120.1.3

The views and opinions expressed or implied in this article are those of the author (or authors) and do not necessarily reflect the position of the National Marine Fisheries Service, NOAA.

\title{
Reproductive characteristics for the blue shark (Prionace glauca) in the North Atlantic Ocean
}

\author{
Katie Viducic ${ }^{1}$ \\ Lisa J. Natanson (contact author) (retired) ${ }^{2}$ \\ Megan V. Winton ${ }^{3}$ \\ Austin Humphries ${ }^{4}$
}

Email address for contact author: mangrules@yahoo.ca

${ }^{1}$ Lynker Technologies LLC for Apex Predators Program

Northeast Fisheries Science Center

National Marine Fisheries Service, NOAA

28 Tarzwell Drive

Narragansett, Rhode Island 02882

${ }^{2}$ Northeast Fisheries Science Center

National Marine Fisheries Service, NOAA

28 Tarzwell Drive

Narragansett, Rhode Island 02882

\author{
${ }^{3}$ Atlantic White Shark Conservancy \\ 235 Orleans Road \\ Chatham, Massachusetts 02650 \\ ${ }^{4}$ University of Rhode Island \\ 120 Flagg Road \\ Kingston, Rhode Island 02881
}

The blue shark (Prionace glauca) is a pelagic species with a circumglobal distribution in tropical, subtropical, and warm temperate seas, including the Mediterranean Sea (Compagno, 1984). This species has long been considered the most abundant of the Atlantic pelagic sharks (Bigelow and Schroeder, 1948), ranging from Newfoundland, Canada, to Argentina in the west, from Norway to South Africa in the east (Bigelow and Schroder, 1948; Castro, 2011), and over the entire mid-Atlantic (Aasen, 1966). Evidence from tagging data indicates that North Atlantic blue sharks constitute a single stock with seasonal latitudinal migrations (Kohler et al., 2002; Kohler and Turner, 2019). Additionally, results from genetic studies indicate not only a single North Atlantic population but a single global blue shark population (Veríssimo et al., 2017). However, differences do exist in various geographic areas in maximum and average size and in size and age at maturity (Skomal and Natanson, 2003; Mejuto and García-Cortés, 2005), making regional studies on life history important for local management.

Different stages of the blue shark reproductive cycle are believed to occur in different areas of the North Atlantic Ocean (Pratt, 1979). The blue shark is a placental viviparous species, with broods usually ranging from 25 to 50 young born after a gestation period of 9-12 months (Pratt, 1979), and Aasen (1966) suggested an average brood size of 45 young in the same area. Brood size in the blue shark appears to be regionally variable (Mejuto and García-Cortés, 2005; Castro, 2011) with up to 135 young reported from a brood in the Indian Ocean (Gubanov and Grigor'yev, 1975) and averages varying from 25.6 young in the North Pacific Ocean (Nakano, 1994) to 37 young in the Gulf of Guinea (Castro and Mejuto, 1995). Brood size has also been shown to increase with female size (Mejuto and García-Cortés, 2005). Although few gravid females in the western North Atlantic Ocean have been reported (Pratt, 1979), many have been caught off the coast of Africa, 
the Madeira Islands, and the Canary Islands (Aasen, 1966; Mejuto and García-Cortés, 2005; Kohler and Turner, 2008), indicating the possibility of offshore parturition grounds. Pratt (1979) suggested that parturition occurs between March and July in the eastern North Atlantic Ocean but noted that young-of-the-year (YOY) individuals are infrequently encountered in coastal waters. In the central North Atlantic Ocean, the presence of mature females in advanced stages of pregnancy during spring and the appearance of the smallest size classes of YOY in early summer indicate that the archipelago of the Azores is a parturition area (Aasen, 1966; Vandeperre et al., 2014). Additionally, the occurrence of neonate- and YOY-sized sharks on the Grand Banks of Newfoundland, a widely used fishing ground off Newfoundland, indicates that this area may also be a parturition or nursery area for the blue shark (L. Natanson, unpubl. data).

Blue sharks represent the most frequently captured shark in the U.S. Atlantic pelagic longline fishery, with high catch rates in the Grand Banks of Newfoundland (Mandelman et al., 2008). Throughout the world's oceans, blue sharks are taken by using diverse fishing gear, but they are caught mostly as bycatch on pelagic longlines targeting tuna and billfish (Bonfil, 1994; Mandelman et al., 2008). Additionally, as other stocks of large pelagic fish species declined, several nations bordering the North Atlantic Ocean specifically targeted blue sharks for their fins and meat (Castro et al., 1999; Mejuto et al., 2002).

Data reported by the International Commission for the Conservation of Atlantic Tunas (ICCAT) indicate that the overall catch of blue sharks in the North Atlantic Ocean increased between 1993 and 2016 (from 9589 metric tons [t] to $44,067 \mathrm{t}$ ), followed by a decrease between 2016 and 2017 (from $44,067 \mathrm{t}$ to $39,675 \mathrm{t}$ ) $\left(\mathrm{ICCAT}^{1}\right.$ ). The North Atlantic blue shark population is not considered overfished at this time (ICCAT ${ }^{1}$ ); however, there is uncertainty in data inputs, such as size, and there were problems with the production models fitting the data, leading to uncertainty in the results. Therefore, the possibility of the stock being overfished or subjected to overfishing cannot be ruled out $\left(\right.$ ICCAT $\left.^{1}\right)$. Recognizing this uncertainty, and that blue sharks are caught in large numbers, the ICCAT recently implemented an annual total allowable catch of $39,100 \mathrm{t}$ for the conservation of blue sharks in the Atlantic Ocean $\left(\right.$ ICCAT $\left.^{2}\right)$.

As fisheries managers set policy guidelines on the basis of the results of stock assessment models that rely on life history data (Hilborn and Walters, 1992), there is a need to understand and periodically reevaluate the life history of a species. Reproductive potential is a vital component of

\footnotetext{
${ }^{1}$ ICCAT (International Commission for the Conservation of Atlantic Tunas). 2018. Report of the Standing Committee on Research and Statistics (SCRS) (Madrid, Spain, 1 to 5 October 2018), 298 p. ICCAT, Madrid, Spain. [Available from website.]

2 ICCAT (International Commission for the Conservation of Atlantic Tunas). 2019. Recommendation by ICCAT amending the recommendation 16-12 on management measures for the conservation of the North Atlantic blue shark caught in association with ICCAT fisheries. ICCAT Rec. 16-12, 2 p. [Available from website.]
}

life history data; however, maturity data on highly migratory pelagic sharks, such as the blue shark, are often lacking (Cortés, 1998; Castro, 2011). Pratt (1979) is the most recent publication specifying sizes at maturity for blue sharks in the western North Atlantic Ocean. Since those data were collected, changes have occurred in fishing pressure, which has been suggested to have the potential to affect the blue shark population $\left(\mathrm{ICCAT}^{1}\right.$ ), and climate change could also alter the biology of species because of changes in prey that lead to shifts in growth (Pinsky et al., 2019). Thus, the objectives of this study were 1) to provide current estimates of size at maturity for blue sharks, including length and weight at median maturity $\left(L_{50}\right.$ and $W_{50}$, respectively) for both sexes, and 2) to determine if changes in reproductive characteristics have occurred over time in the blue shark.

\section{Materials and methods}

\section{Specimen collection}

Specimens of blue sharks were collected opportunistically between 1971 and 2016 from commercial and recreational fishermen, at shark tournaments, and during National Marine Fisheries Service research surveys along the northeastern coast of North America, between New Jersey and the Flemish Cap. A subset of the maturity data analyzed (number of samples $[n]=338$ ) was previously used to estimate maturity parameters by Pratt (1979). For most specimens, full dissections were completed by experienced personnel using consistent protocols. Because of time constraints during shark tournaments, it was not always possible to complete a full dissection on each specimen. When time was limited, an assignment of maturity was made through visual examination of organ condition on the basis of the dissectors' experience of organ maturity from previous detailed dissections.

\section{Morphometrics}

Fork length (FL) was measured in centimeters on each specimen following Kohler et al. (1995; from the tip of the snout to the fork of the tail, over the curvature of the body). Individuals were weighed (in pounds or kilograms) when possible; all weights were converted to kilograms. To allow direct comparison to data from this study, median total lengths (TLs) at maturity presented in other studies (Megalofonou et al., 2009; Carrera-Fernández et al., 2010; Bustamante and Bennett, 2013; Jolly et al., 2013) were converted to FL by using the following equation from Kohler et al. (1995):

$$
F L=0.8313(T L)+1.3908 \quad\left(n=572, r^{2}=0.99\right) .
$$

\section{Maturity}

Maturity condition was determined by measurements and visual examinations noting condition and appearance of 
external and internal reproductive organs following Pratt (1979). Reproductive terminology follows Pratt (1979), Hamlett (1999), and Hamlett and Koob (1999). Only the right ovary in the blue shark is functional (Pratt, 1979); thus, for all specimens, reproductive organs from the right side of the body were measured to the nearest millimeter to ensure consistency. Each fish was examined fresh to assign a mature or immature (juvenile) status, and detailed conditions, such as foreign objects in the body or excessive thinness, etc., were noted. Mature females were further classified as gravid or postpartum when appropriate. Gravid females contained embryos, and postpartum females had evidence of recent past pregnancy, such as flaccid uteri or ovaries in the process of oogenesis. Juveniles with lengths between the smallest mature and largest immature sizes (transitional range) were further examined given that these sizes were in the range of median size at maturity, and because of the gradual nature of maturation, it was difficult to ascertain their condition.

Female blue sharks were visually examined for the presence or absence of mating scars or injuries. Internal measurements included the width (measured at the widest point) of the upper oviduct and oviducal gland, uterus width and length, and ovary width and length. The diameter of the largest oocyte was measured, and the presence or absence of the vaginal membrane (hymen) was determined by insertion of a probe through the posterior end of the uterus into the cloaca; the latter was used as an indicator of prior mating activity.

For males, maturity was externally assessed by examination of clasper condition on the basis of degree of clasper calcification (fully calcified, partially calcified, or uncalcified), ability of the clasper to easily rotate around the base, and the ability of the rhipidion to open (Clark and von Schmidt, 1965). Clasper length was measured on the external side from the insertion of the pelvic fin to the tip of the clasper. Siphon sacs, which lie between the skin and the abdominal musculature, were measured as per Natanson and Gervelis (2013). Internal measurements for males included epididymis width, ampulla epididymis width, and testis length and width. Presence or absence of spermatophores was noted, as was coiling of the epididymis.

For sharks that did not undergo a full workup, maturity was assessed on the basis of visual examination following criteria from Pratt (1979). In females, the condition of the epigonal tissue encasing the ovaries, presence and size of oocytes, and the general appearance of the upper oviduct, oviducal gland, and uterus were examined. In males, the clasper condition (as described in the previous paragraph), the amount of the epigonal tissue surrounding the testis, and coiling of the epididymis were examined. The specimens were then classified on the basis of development of these characteristics.

Measurements of the reproductive organs of both sexes were plotted against FL to examine the growth of the organs throughout ontogeny. Those specimens not assigned a maturity status at the time of dissection were later classified on the basis of comparisons of organ measurements in relation to FL, comparisons with organ measurements of staged individuals, and detailed notes on condition taken at dissection. Non-staged specimens within the transitional size range could not be assigned a status by using measurements alone because of the overlap of immature and mature stages in this size range. For some samples, there was not enough information to confirm maturity stage; thus, none of these samples were used in the ogive analyses.

Pratt (1979) assigned 3 maturity stages for female blue sharks: immature (46.0-145.0 cm FL), subadult (145.0$185.0 \mathrm{~cm} \mathrm{FL})$, and mature (185.0-300.0 cm FL). In the subadult phase, the organs necessary for copulation were developed, while those required for generation (such as oviducal gland and ovaries) were still developing. Therefore, for ogive analysis in our study, we considered immature any samples that would be assigned to the subadult stage in his classification.

\section{Median maturity analysis}

Median FL and weight at maturity were calculated for both sexes by using maturity ogives fit to binomial data on reproductive maturity status. The probability that a given individual $i$ was mature was modeled as the outcome of a Bernoulli random variable, where $y_{i}$ is 0 for immature individuals and is 1 for mature individuals:

$$
y_{\mathrm{i}} \sim \operatorname{Bernoulli}\left(p_{\mathrm{i}}\right)
$$

where $p_{\mathrm{i}}=$ the probability that shark $i$ is mature.

To examine life history changes through time, samples were divided into 2 discrete time periods (TPs). Time period 1 (TP1) corresponded to the data collected during 19711977, data that were originally analyzed by Pratt (1979). Time period 2 (TP2) included specimens collected during 2003-2016, primarily by L. Natanson. The gap between time periods is approximately 5 generations, allowing time for density-dependent changes in life history.

We modeled $p_{\mathrm{i}}$ as a function of size (separately in terms of FL and weight) and time period as follows, with the logit link function constraining $p_{\mathrm{i}}$ to values between 0 and 1 :

$$
\operatorname{logit}\left(p_{\mathrm{i}}\right)=\beta_{0}+\beta_{1, \text { Period }} \text { Size }_{\mathrm{i}},
$$

where $\beta_{0}=$ an intercept term representing the mean probability that a shark is mature; and

$\beta_{1}=$ the time-period-specific effect of size in terms of either FL or weight.

Models were fit to data on each sex separately by using maximum likelihood methods with functions available in $\mathrm{R}$, vers. 3.6.3 (R Core Team, 2017). Models were run separately by sex because it is well-documented that life history characteristics (e.g., size at maturity) differ between male and female elasmobranchs (Cortés, 2000). Model fit was evaluated by using the Akaike information criterion corrected for small sample sizes $\left(\mathrm{AIC}_{\mathrm{c}}\right.$ ) (Akaike, 1973; Burnham and Anderson, 2002). The best fitting model was the model with the lowest $\mathrm{AIC}_{\mathrm{c}}$ value. The difference in $\mathrm{AIC}_{\mathrm{c}}$ between each model $\left(\Delta_{\mathrm{i}}\right)$ was calculated as $\Delta_{\mathrm{i}}=A I C_{\mathrm{c}, \mathrm{i}}-A I C_{\mathrm{c}, \min }$, where $A I C_{\mathrm{c}, \mathrm{i}}$ is the $\mathrm{AIC}_{\mathrm{c}}$ for time period $i$ and $A I C_{\mathrm{c}, \min }$ is the lowest $\mathrm{AIC}_{\mathrm{c}}$ 
for the best fitting model (Burnham and Anderson, 2002). Models with $\Delta_{\mathrm{i}}$ values $\leq 2$ are indicative of no evidence of a statistical difference between models. Those with $\Delta_{\mathrm{i}}$ values $>10$ are indicative of poor fit relative to the best fitting model and are generally unsupported.

On the basis of the selected model, the median size at maturity (i.e., $L_{50}$ or $W_{50}$, the inflection point of the relationship where $P=0.5$ ) was calculated from the fitted model parameters as $-\beta_{0} / \beta_{1}$. Confidence intervals around $L_{50}$ and $W_{50}$ were bootstrapped from the selected model to 1000 repeated samplings of the maturity data (Harry et al., 2013) by using the boot package (vers. 1.3-20; Canty and Ripley, 2017) in R. For all models, normalized diagnostic plots of the residuals were examined visually to evaluate the appropriateness of model assumptions (Zuur et al., 2010).

\section{Revisiting Pratt (1979)}

Pratt (1979) did not present a value for median size at maturity for females. Using Pratt's data (TP1) and staging the subadult phase as immature, we calculated median size at maturity for females. Additionally, for comparison to his analysis, we calculated the male median sizes at maturity using the TP1 data.

\section{Median age at maturity}

To improve existing age-structured relationships, age at median maturity was estimated by inserting the calculated
$L_{50}$ for each sex into the sex-specific von Bertalanffy growth functions calculated by Skomal and Natanson (2003).

\section{Results}

\section{Specimen collection}

A total of 857 blue sharks were dissected for reproductive analysis (488 males and 369 females) between 1971 and 2016. Samples were obtained in all months, with most of the samples obtained between June and September $(79.3 \%, n=680)$ and the remainder between October and May (20.6\%, $n=177)$ (Table 1). Recreational fishermen caught the majority of sharks $(66.6 \%, n=571)$, followed by commercial fishermen $(23.3 \%, n=201)$, and scientists on research vessels $(8.8 \%, n=75)$. The source of $1.3 \%(n=11)$ of samples could not be determined because the source was not noted at the time of dissection (Suppl. Table 1). Sharks from the entire study ranged in size between 62.0 and $300.0 \mathrm{~cm} \mathrm{FL}$ and between 1.0 and $213.4 \mathrm{~kg}$, although size ranges of samples and number of samples were different in each time period and analysis (Table 1).

\section{Maturity}

Females Data collected from 1971 through 2016 were used to examine female reproductive condition (see the

\section{Table 1}

Number and size range (in centimeters and kilograms) of blue sharks (Prionace glauca) by sex, time period (TP), and month of capture per TP in the western North Atlantic Ocean along the northeastern coast of North America between New Jersey and the Flemish Cap. Sampling occurred in 2 TPs: 1971-1977 (TP1) and 2003-2016 (TP2). Values are also provided for the interim period of 1978-2002. $n=$ number of samples.

\begin{tabular}{|c|c|c|c|c|c|c|}
\hline & \multicolumn{3}{|c|}{ Males } & \multicolumn{3}{|c|}{ Females } \\
\hline & TP1 & 1978-2002 & TP2 & TP1 & 1978-2002 & TP2 \\
\hline$n$ & 155 & 109 & 224 & 183 & 76 & 110 \\
\hline Fork length (cm) & $102.0-279.0$ & $62.0-285.0$ & $64.7-300.0$ & $108.0-263.0$ & $114.0-273.0$ & $63.0-257.0$ \\
\hline Weight (kg) & $17.7-122.5$ & $1.0-174.0$ & $1.4-213.4$ & $9.1-112.5$ & $8.2-146.0$ & $1.7-110.0$ \\
\hline January & 0 & 0 & 0 & 0 & 1 & 0 \\
\hline February & 0 & 2 & 0 & 0 & 4 & 0 \\
\hline March & 6 & 2 & 0 & 6 & 2 & 0 \\
\hline April & 1 & 2 & 0 & 1 & 3 & 0 \\
\hline May & 40 & 4 & 0 & 3 & 2 & 0 \\
\hline June & 36 & 35 & 105 & 65 & 38 & 9 \\
\hline July & 56 & 47 & 46 & 53 & 15 & 1 \\
\hline August & 1 & 7 & 21 & 15 & 7 & 10 \\
\hline September & 2 & 2 & 43 & 21 & 0 & 45 \\
\hline October & 13 & 3 & 9 & 19 & 0 & 45 \\
\hline November & 0 & 4 & 0 & 0 & 4 & 0 \\
\hline December & 0 & 1 & 0 & 0 & 0 & 0 \\
\hline
\end{tabular}


"Median maturity analysis" section). Maturity condition was not defined for 54 specimens, of which 30 specimens were in the transitional size range and thus could not be judged. Data collected on the additional 24 specimens was not sufficient to determine reproductive condition; therefore, these specimens were not assigned a reproductive condition and were not used in ogive analysis. A sharp increase in growth of organ size relative to FL was apparent in all reproductive organs of females (Fig. 1, Suppl. Figs. 1-3).

Juvenile females ranged in size between 63.1 and $206.0 \mathrm{~cm} \mathrm{FL}$ and between 1.7 and $59.0 \mathrm{~kg}(n=238)$. Juveniles lacked mating scars and possessed a vaginal membrane. Juvenile females possessed a thin oviduct and varying stages of differentiation of the oviducal gland. In the smallest samples, the right oviducal gland was small and barely distinguishable from the oviduct. Additionally, the paired uteri were thin and indistinguishable from the lower portion of the oviduct; as growth progresses these organs enlarge and become more defined. Ovaries in juveniles were enclosed in epigonal tissue, and the smallest individuals had no oocytes visible to the naked eye (Table 2).

Because of the gradual process of maturity, there is a transitional size range between the smallest mature and largest juvenile fish (173.0-206.0 cm FL and $28.1-59.0 \mathrm{~kg}$ ). In this size range, specimens can be mature or immature. The organs of juveniles can have both mature and immature characteristics because the organs develop at differing rates. Fifty-six juveniles fell within this size range. In general, the ovaries of juveniles in the transitional size range were developing oocytes $(4.0-16.0 \mathrm{~mm})$, the oviducal gland was expanding and becoming differentiated from the oviduct $(22.0-35.0 \mathrm{~mm})$, and the uterus had begun to thicken (Table 2, Fig. 1, Suppl. Figs. 1-3).

Mature females ranged in size between 173.0 and $273.0 \mathrm{~cm}$ FL and between 32.7 and $146.0 \mathrm{~kg}(n=77)$. The uterus of mature females varied in size and elasticity, a flaccid uterus indicated recent or past pregnancy, and gravid females carried embryos (Table 2, Suppl. Fig. 3). Mature ovaries ranged from developing new oocytes $(\sim 4.0 \mathrm{~mm})$ after recent birth
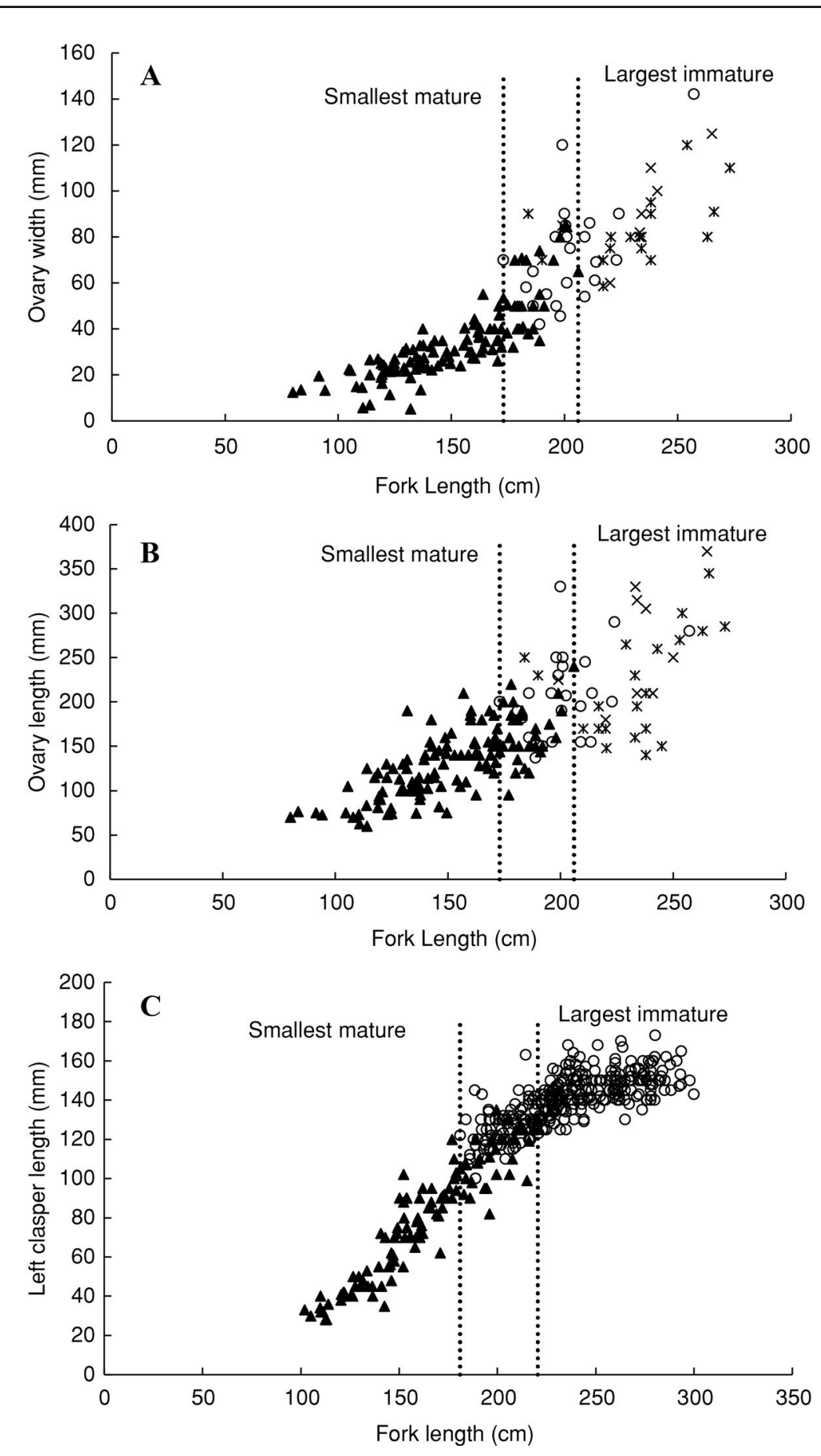

Figure 1

Relationships of (A) ovary width (in millimeters) and (B) ovary length (in millimeters) to fork length (in centimeters) of female blue sharks (Prionace glauca) and of (C) left clasper length (in millimeters) to fork length (in centimeters) of male blue sharks caught during 1971-2016 in the western North Atlantic Ocean along the northeastern coast of North America between New Jersey and the Flemish Cap, by maturity stage. Black triangles and open circles indicate specimens of both sexes in the immature and mature stages, respectively. Symbols indicate further classification of mature females as gravid (*) or postpartum ( $\times$ ). The vertical dotted lines represent the lengths of the smallest mature and largest immature samples. 


\section{Table 2}

Ranges of measurements and descriptions of organs used to determine maturity stages of female blue sharks (Prionace glauca) captured in the western North Atlantic Ocean between New Jersey and the Flemish Cap during 1971-2016. Sharks in the size ranges associated with the juvenile and mature stages generally conform to those assignments (unless otherwise noted); whereas, sharks in the transitional size range can be either immature or mature and represent the size of the smallest mature and largest juvenile fish. The table format is adapted from Walker (2005). $n=$ number of samples.

\begin{tabular}{|c|c|c|c|}
\hline Organ & $\begin{array}{l}\text { Range of organ } \\
\text { measurement } \\
\quad(\mathrm{mm})\end{array}$ & Description & $\begin{array}{l}\text { Maturity } \\
\text { stage }\end{array}$ \\
\hline $\begin{array}{l}\text { Ovary length } \\
(n=183)\end{array}$ & $\begin{array}{l}\leq 136 \\
<136 \text { to }>240 \\
\geq 240\end{array}$ & $\begin{array}{l}\text { Enclosed in epigonal tissue, clear or no visible oocytes } \\
\text { Thinning epigonal tissue, follicles become opaque } \\
\text { Little epigonal tissue, oocytes range from new developing to turgid } \\
\quad \text { yolked oocytes }\end{array}$ & $\begin{array}{l}\text { Immature } \\
\text { Transitional } \\
\text { Mature }\end{array}$ \\
\hline $\begin{array}{l}\text { Ovary width } \\
(n=159)\end{array}$ & $\begin{array}{l}\leq 42 \\
<42 \text { to }>80 \\
\geq 80\end{array}$ & $\begin{array}{l}\text { Thin, difficult to distinguish from epigonal tissue } \\
\text { Thinning epigonal tissue, widening with developing oocytes } \\
\text { Thin epigonal tissue, defined shape, follicles range from new } \\
\text { developing to turgid yolked oocytes }\end{array}$ & $\begin{array}{l}\text { Immature } \\
\text { Transitional } \\
\text { Mature }\end{array}$ \\
\hline $\begin{array}{l}\text { Egg diameter } \\
(n=296)\end{array}$ & $\begin{array}{l}\leq 4 \\
>4 \text { to }<16 \\
\geq 16\end{array}$ & $\begin{array}{l}\text { Clear or non-visible follicles, contained in layer if generative tissue } \\
\text { Follicles become opaque } \\
\text { Yolked oocytes }\end{array}$ & $\begin{array}{l}\text { Immature } \\
\text { Transitional } \\
\text { Mature }\end{array}$ \\
\hline $\begin{array}{l}\text { Oviducal gland width } \\
(n=273)\end{array}$ & $\begin{array}{l}\leq 22 \\
>22 \text { to }<35 \\
\geq 35\end{array}$ & $\begin{array}{l}\text { Thin, undifferentiated from the upper oviduct } \\
\text { Begins to take shape, differentiated from the upper oviduct } \\
\text { Plump, heart shaped }\end{array}$ & $\begin{array}{l}\text { Immature } \\
\text { Transitional } \\
\text { Mature }\end{array}$ \\
\hline $\begin{array}{l}\text { Uterus width } \\
(n=290)\end{array}$ & $\begin{array}{l}\leq 14 \\
>14 \text { to }<35 \\
\geq 35\end{array}$ & $\begin{array}{l}\text { Thin, undifferentiated from the oviduct } \\
\text { Widens from the oviduct } \\
\text { Tissue thickens, elastic or flaccid }\end{array}$ & $\begin{array}{l}\text { Immature } \\
\text { Transitional } \\
\text { Mature }\end{array}$ \\
\hline $\begin{array}{l}\text { Uterus length } \\
(n=91)\end{array}$ & $\begin{array}{l}\leq 260 \\
>260 \text { to }<540 \\
\geq 540\end{array}$ & $\begin{array}{l}\text { Thin, undifferentiated from the oviduct } \\
\text { Differentiated from the oviduct, widening and elongated } \\
\text { Elongated and flaccid }\end{array}$ & $\begin{array}{l}\text { Immature } \\
\text { Transitional } \\
\text { Mature }\end{array}$ \\
\hline $\begin{array}{l}\text { Upper oviduct width } \\
(n=132)\end{array}$ & $\begin{array}{l}\leq 5 \\
>5 \text { to }<12 \\
\geq 12\end{array}$ & $\begin{array}{l}\text { Thin tube } \\
\text { Thickens, differentiated from oviducal gland }\end{array}$ & $\begin{array}{l}\text { Immature } \\
\text { Transitional } \\
\text { Mature }\end{array}$ \\
\hline
\end{tabular}

to turgid, large oocytes $(29.0 \mathrm{~mm})$ that were ready for ovulation (Table 2, Suppl. Fig. 1). In mature specimens, the oviduct was fully differentiated from the oviducal gland, which was plump, heart shaped, and $\geq 35 \mathrm{~mm}$ in width. The status of mature females was further staged as gravid $(n=32)$ and postpartum $(n=11)$.

Males Data collected from 1971 through 2016 were examined to determine male reproductive condition (see the "Median maturity analysis" section). Sharp increases in organ size relative to FL for clasper length, testis length, and epididymis width indicate that they are good indicators of $L_{50}$ (Fig. 1, Suppl. Fig. 4). In contrast, the siphon sac length, ampulla epididymis width, and testis width had slower gradual growth when plotted against FL and are not adequate indicators of $L_{50}$.

Immature males $(n=148)$ ranged between 64.7 and $220.5 \mathrm{~cm} \mathrm{FL}$ and between 1.4 and $68.5 \mathrm{~kg}$, and they were characterized externally by soft, uncalcified, or partially calcified claspers that resisted rotation and opening of the tip (Table 3 ). The siphon sacs of juvenile males were constricted and did not extend fully to the pectoral girdle. In this stage, the epididymis was thin and straight, and the testes were entirely encompassed in epigonal tissue. In some juvenile males, sperm was present.

Immature males in the transitional size range were maturing, and their organs often had both mature and immature characteristics. Although most fish in this size range were staged as mature or immature, data collected on 5 specimens (180.5-191.2 cm FL) did not provide enough information to determine reproductive condition; therefore, these specimens were not assigned a condition and were not used in ogive analysis. Immature sharks in the transitional range were found to have testes enclosed in thinning epigonal tissue, a coiled epididymis, and flexible claspers. In 5 cases, males with mature internal organs had partially calcified claspers. These individuals ranged in size between 188.5 and $228.0 \mathrm{~cm}$ FL, overlapping the transitional size range that may indicate that clasper calcification is the best indicator of maturity.

Mature males ranged between 181.0 and $300.0 \mathrm{~cm}$ FL and between 35.4 and $213.4 \mathrm{~kg}(n=331)$. Claspers of mature males (>220.5 cm FL) were elongated $(\geq 123 \mathrm{~mm}$; Fig. 1), fully calcified, easily rotated, and opened at the tip. A mature epididymis was heavily coiled, and the mature testis was surrounded by a thin layer of epigonal tissue 


\section{Table 3}

Ranges of measurements and descriptions of organs used to determine maturity stages of male blue sharks (Prionace glauca) captured in the western North Atlantic Ocean between New Jersey and the Flemish Cap during 1971-2016. Sharks in the size ranges associated with the immature and mature stages generally conform to those assignments (unless otherwise noted); whereas, sharks in the transitional size range can be either immature or mature and represent the size of the smallest mature and largest immature fish. The table format is adapted from Walker (2005). $n=$ number of samples.

\begin{tabular}{|c|c|c|c|}
\hline Organ & $\begin{array}{l}\text { Range of } \\
\text { measurement } \\
\quad(\mathrm{mm})\end{array}$ & Description & $\begin{array}{l}\text { Maturity } \\
\text { stage }\end{array}$ \\
\hline $\begin{array}{l}\text { Left clasper length } \\
(n=434)\end{array}$ & $\begin{array}{l}\leq 99 \\
>99 \text { to }<135 \\
\geq 135\end{array}$ & $\begin{array}{l}\text { Soft and uncalcified, resists rotation and flexing of the tip } \\
\text { Soft or plastic, begins to rotate } \\
\text { Calcified, easy rotation and flexing of the tip }\end{array}$ & $\begin{array}{l}\text { Immature } \\
\text { Transitional } \\
\text { Mature }\end{array}$ \\
\hline $\begin{array}{l}\text { Epididymis width } \\
(n=330)\end{array}$ & $\begin{array}{l}\leq 13 \\
>13 \text { to }<23 \\
\leq 23\end{array}$ & $\begin{array}{l}\text { Thin and straight } \\
\text { Coiling begins } \\
\text { Thickened and heavily coiled }\end{array}$ & $\begin{array}{l}\text { Immature } \\
\text { Transitional } \\
\text { Mature }\end{array}$ \\
\hline $\begin{array}{l}\text { Testis length } \\
(n=322)\end{array}$ & $\begin{array}{l}\leq 105 \\
>105 \text { to } 190 \\
\geq 190\end{array}$ & $\begin{array}{l}\text { Thin, encompassed in epigonal tissue } \\
\text { Thinning epigonal tissue, elongated } \\
\text { Elongated, distended }\end{array}$ & $\begin{array}{l}\text { Immature } \\
\text { Transitional } \\
\text { Mature }\end{array}$ \\
\hline
\end{tabular}

(Table 3). Sperm and spermatophores were observed in all mature males for which this factor was examined.

\section{Median maturity analysis}

Females Variation in size at maturity for females was best described by maturity ogives based only on FL or weight, indicating no evidence of difference in $L_{50}$ or $W_{50}$ between time periods (Table 4, Suppl. Table 2); therefore, all data from 1971 through 2016 were used to define the size at median maturity. On the basis of maturity ogives, the size at median maturity of female blue sharks is $190.9 \mathrm{~cm} \mathrm{FL}$ and $50.1 \mathrm{~kg}$ (Table 4, Fig. 2).

Males Contrary to the results for females, results from the best fitting model for males indicate an increase in $L_{50}$ and $W_{50}$ between time periods (Table 4, Suppl. Table 2).
Estimated median maturity for TP2 occurred at $211.2 \mathrm{~cm}$ FL and $62.3 \mathrm{~kg}$, which represent rather large increases from TP1 (184 cm FL and $35.6 \mathrm{~kg}$ ). Upon further examination, there appeared to be clear differences in the sampled size distribution between time periods, with TP2 having more large fish (>220 cm FL) and fewer samples in the range of 160-220 cm FL than TP1 (Table 4, Fig. 3). The absence of juvenile males in the range of $220-240 \mathrm{~cm}$ FL during TP1, and the presence of juvenile males in the range of 220-240 cm FL during TP2, may indicate an increase in size at maturity over time. However, there is evidence of large juveniles in the interim period (19782002), and this evidence indicates that large juveniles were in this size range prior to TP2 and were probably under-sampled because of low sample size in this size range in TP1. Because the large juvenile males were present, the difference observed between TP1 and TP2 is

\section{Table 4}

Median fork length (FL in centimeters) and weight (in kilograms) at maturity ( $L_{50}$ and $W_{50}$, respectively) and size range (in centimeters and kilograms) of blue sharks (Prionace glauca) captured in the western North Atlantic Ocean between New Jersey and the Flemish Cap. Sampling occurred in 2 time periods: 1971-1977 (TP1) and 2003-2016 (TP2). Values are also provided for the interim period of 1978-2002. $n=$ number of samples.

\begin{tabular}{|c|c|c|c|c|c|c|c|c|c|c|c|c|}
\hline \multirow[b]{2}{*}{ Period } & \multicolumn{4}{|c|}{ Size range $(\mathrm{cm} \mathrm{FL})$} & \multicolumn{2}{|c|}{$L_{50}$} & \multicolumn{4}{|c|}{ Size range $(\mathrm{kg})$} & \multicolumn{2}{|c|}{$W_{50}$} \\
\hline & Female & $n$ & Male & $n$ & Female & Male & Female & $n$ & Male & $n$ & Female & Male \\
\hline TP1 & $108.0-263.0$ & 134 & $102.0-279.0$ & 155 & 190.6 & 184.1 & $9.1-112.5$ & 80 & $17.7-122.5$ & 33 & 50.8 & 35.6 \\
\hline TP2 & $114.0-273.0$ & 110 & $64.7-300.0$ & 224 & 189.8 & 211.2 & $1.7-110.0$ & 56 & $1.4-213.4$ & 199 & 43.5 & 62.3 \\
\hline TP1 and TP2 & $63.1-257.2$ & 244 & $64.7-300.0$ & 379 & 189.8 & 191.2 & $1.7-112.5$ & 136 & $1.4-213.4$ & 232 & 48.3 & 50.7 \\
\hline 1971-2016 & $63.1-273.0$ & 315 & $62.0-300.0$ & 488 & 190.9 & 192.5 & $1.7-146.0$ & 188 & $1.0-213.4$ & 319 & 50.1 & 49.5 \\
\hline
\end{tabular}




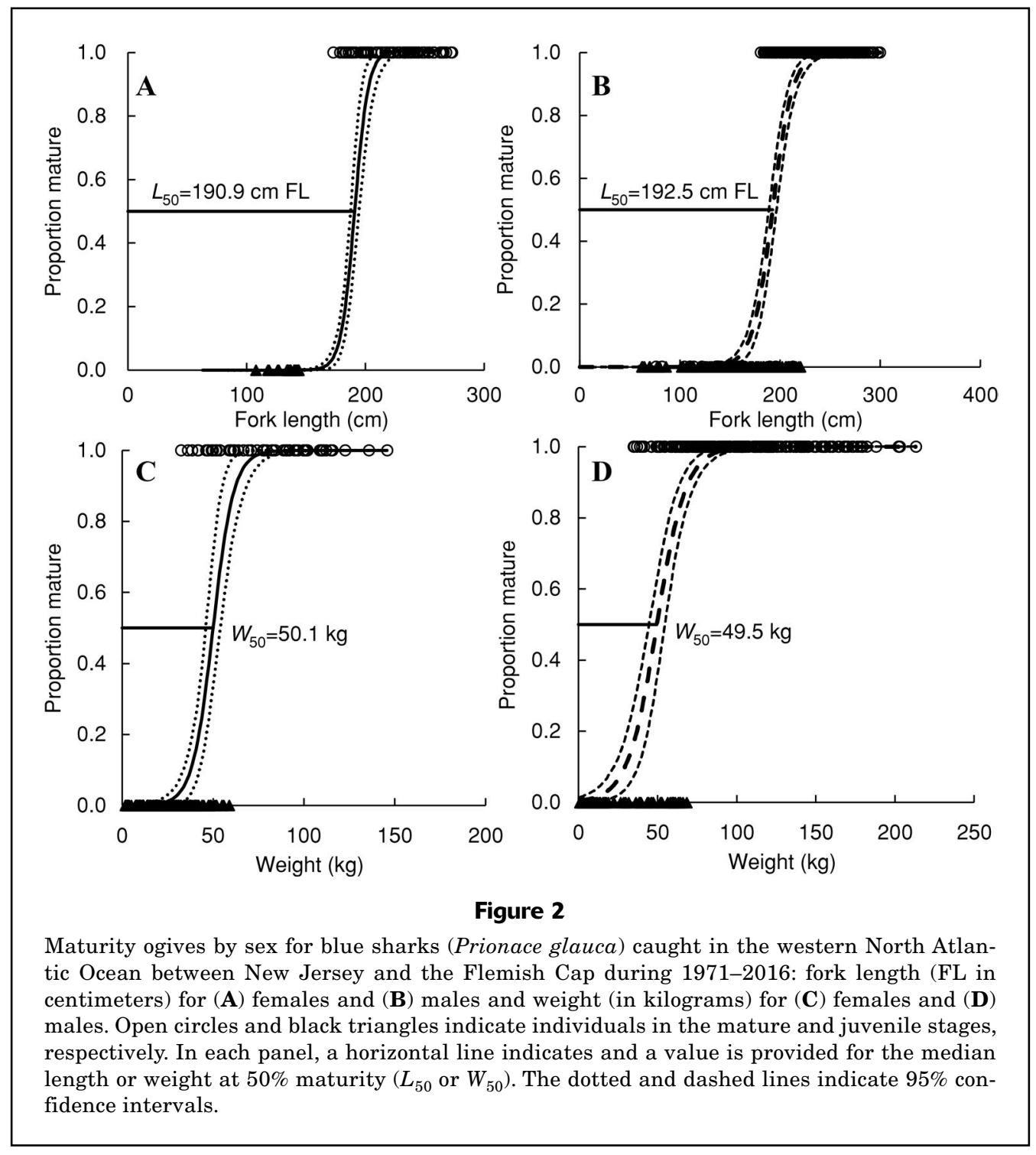

likely the result of sampling bias rather than a biologically significant difference. We therefore combined the data for all time periods to provide an updated size at median maturity for males of $192.5 \mathrm{~cm} \mathrm{FL}$ and $49.5 \mathrm{~kg}$ and feel this estimate of current reproductive parameters for the population is robust (Fig. 2).

\section{Revisiting Pratt (1979)}

For male blue sharks, we used Pratt's (1979) original staging and found that his estimate of average size at maturity of $183.0 \mathrm{~cm} \mathrm{FL}$ is lower than our calculated estimate of median maturity (184.1 cm FL) for TP1. We analyzed the female data from Pratt (1979), producing an $L_{50}$ of $190.6 \mathrm{~cm}$ FL, which is slightly higher than Pratt's estimated size at first maturity of $185.0 \mathrm{~cm}$ FL. Pratt (1979) did not calculate median size at maturity for females; therefore, $L_{50}$ values calculated from his data for TP1 were used for comparison.

\section{Median age at maturity}

When the median $L_{50}$ for each sex was combined with the published growth curves from Skomal and Natanson (2003), age at median maturity stayed stable at 5 years for both sexes.

\section{Discussion}

Changes in life history characteristics in response to environmental conditions or fishing pressure over time are a concern, particularly with climate change. Additionally, having up-to-date sex-specific inputs is important for management. Results from the statistical comparisons between current and past reproductive characteristics in this study indicate a difference in the parameter estimates for male blue sharks while estimates for females have remained unchanged since the 1970 s. For females, $L_{50}$ 


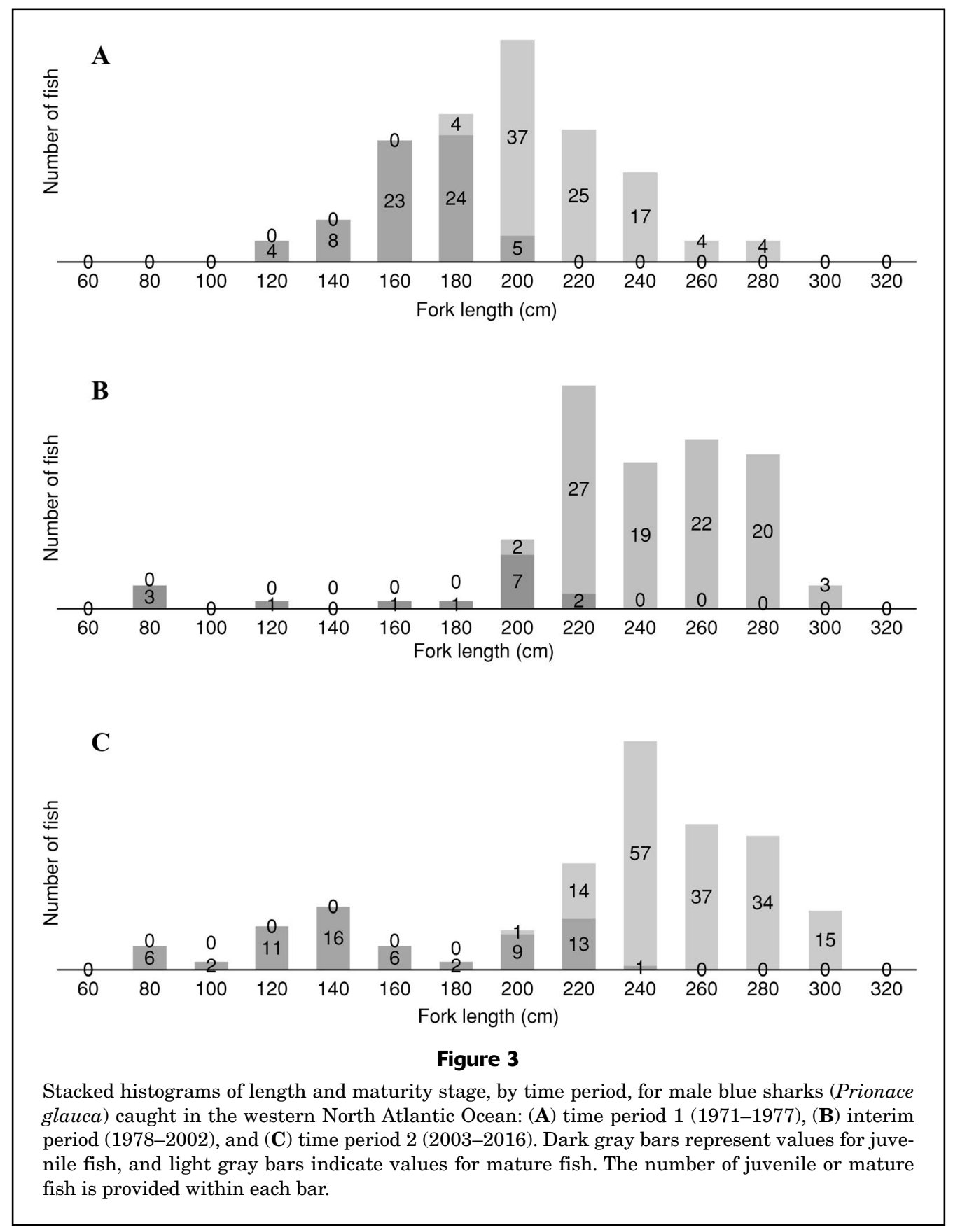

varied slightly, within $10 \mathrm{~mm}$ FL for all time periods, and the $L_{50}$ for males increased from Pratt's (1979) estimate (183.0 cm FL original, or $184.1 \mathrm{~cm}$ FL recalculated) regardless of what comparison was used (Table 4). However, it is important to determine if this change is real or an artifact of sampling method or sample distribution.

In previous studies on the shortfin mako (Isurus oxyrinchus) (Natanson et al., 2020) and the common thresher shark (Alopias vulpinus) (Natanson and Gervelis, 2014), comparisons of data over a 40-year period have shown that changes in principal dissectors over time did not affect the data, indicating that, probably because of intensive training and standard protocols, personnel changes were not a factor leading to the maturity shift. However, we had to consider the possibility that changes in maturity analyses or personnel conducting the study may have influenced these results. For example, Pratt (1979) based maturity status on the presence of spermatophores. The current standard for male maturity is clasper calcification (Castro, 2011). Spermatophores have actually been shown to be present before clasper calcification in a variety of species (Castro, 2011), and such presence of spermatophores may have biased the data toward a lower median size at maturity. We restaged data from Pratt (1979) on the basis of 
clasper calcification and found that his estimate of size at median maturity of $183.0 \mathrm{~cm} \mathrm{FL}$ is similar to our recalculated estimate of $184.1 \mathrm{~cm} \mathrm{FL}$, indicating that our methods for calculating maturity were not the cause of the shift in $L_{50}$ between time periods. Therefore, we conclude on the basis of training and the consistency in results from use of old and new maturity criteria that the differences between time periods are not an artifact of method in dissection, personnel changes, or data analysis.

Another factor that may influence the shift in $L_{50}$ between time periods is sample size distribution and sample availability. The interim period and TP2 both had a larger sample size of bigger sharks than TP1 and, thus, a higher likelihood of larger juvenile specimens, which is what we find in the data (Fig. 3). Because the large (>200 cm FL) juvenile specimens in the interim period were collected close to TP1, it is probable that these specimens were in the western North Atlantic Ocean during TP1, just not sampled, leading to an underestimate of size at maturity in Pratt (1979) and indicating that the real $L_{50}$ was higher at that time and thus no significant change has actually occurred in male characteristics.

We hypothesize that the initiation of shark management led to an increase in large samples in TP2 (Table 4). The increase in sampling of large fish meant that more large juveniles were sampled; large juveniles are proportionally low and were not sampled in TP1 because of a lower overall number of large sharks. Fishing pressure and fisheries management have changed dramatically since the study of Pratt (1979) and were hypothesized to have influenced blue shark sample distribution between TP1 and TP2. Shark management did not start in earnest until the interim period between TP1 and TP2 of this study, meaning that data collection in TP1 was fairly unrestricted and varying size ranges were available. The majority of sampling in all years was conducted at recreational shark tournaments along the East Coast of the United States (Suppl. Table 1). Early in these tournaments there were no federal, state, or in most cases even tournament catch restrictions of size or number (Castro, 2011). It was not until 1993, when the National Marine Fisheries Service implemented the fishery management plan for sharks of the Atlantic Ocean (NMFS, 1993), that tournament and recreational bag and size limits were imposed (NMFS, 2006). Although some tournaments always had size minima, more of them began to implement size restrictions that were often far higher than those of the federal regulations once management was in place (L. Natanson, unpubl. data). Together, the restrictions of tournaments and federal regulations led to greater sampling of larger sharks. Because the majority of the sampling came from recreational fishermen at tournaments, the sample distribution became skewed to large fish (Fig. 3). Additionally, this influx of large fish led to the increased likelihood of observing large juvenile fish, which are proportionally rarer than the mature fish of that size. The presence of large juveniles would influence the results of the ogive analysis, leading to a higher $L_{50}$, as we have observed in this study.

Typically, female elasmobranchs reach a larger size than males, presumably because of the need to accommodate gestation (Cortés, 2000). However, in global studies on the blue shark, males have been observed to be larger than females (McKenzie and Tibbo, 1964; Aasen, 1966; Skomal and Natanson, 2003). Similar to our results, median size at maturity of males was found to be greater than that of females in South Africa (Jolly et al., 2013). The $L_{50}$ from our study is greater than those found in other studies of blue sharks globally (Table 5). Pratt (1979) and Hazin and Lessa (2005) reported that both sexes reached first maturity at 5 years; whereas, we found $50 \%$ maturity at 5 years, indicating a lower age at maturity for this region. Jolly et al. (2013) reported on differences in age at maturity between the sexes, with males maturing at 7 years as opposed to females maturing at 6 years, again indicating regional differences in life history characteristics despite genetic similarity of this species globally (Veríssimo et al., 2017).

Differences in growth rates between populations of the same species of sharks have been well-documented and found to occur both regionally (e.g., the blacknose shark,

\section{Table 5}

Comparison of lengths at median maturity $\left(L_{50}\right)$ of blue sharks (Prionace glauca) from various life history studies. Measurements of $L_{50}$ have been converted to fork length (FL) by using the relationships from Kohler et al. (1996). The estimated $L_{50}$ of blue sharks in this study represents data collected between 1971 and 2016. NA=not available because a length for females was not reported in the source.

\begin{tabular}{llcr}
\hline & & \multicolumn{2}{c}{ Length (cm FL) } \\
\cline { 3 - 4 } Region & Source & Female & Male \\
\hline Western North Atlantic Ocean & This study & 190.9 & 192.5 \\
Mediterranean Sea & Megalofonou et al. (2009) & 179.9 & 170.1 \\
Baja California Sur, Mexico & Carrera-Fernández et al. (2010) & 164.3 & 154.4 \\
South-east Pacific Ocean & Bustamante and Bennett (2013) & 167.0 & 159.6 \\
South Africa & Jolly et al. (2013) & 163.0 & 168.8 \\
New Zealand & Francis and Maolagáin (2016) & NA & 179.4 \\
& & & \\
\hline
\end{tabular}


Carcharhinus acronotus, in the Gulf of Mexico versus the western North Atlantic Ocean; Driggers et al., 2004) and over ocean basins (e.g., porbeagle, Lamna nasus; Natanson et al., 2002; Francis et al., 2008). Different environmental conditions can affect growth and other biological processes of marine apex predators (Izzo and Gillanders, 2020). Blue sharks living under different oceanic conditions could have different growth and other life history characteristics (Megalofonou et al., 2009). Thus, it is not surprising that differences exist between oceans in the median size and age at maturity of blue sharks.

The ability to compensate for fishing-induced changes in life history has important implications for the regulation and sustainability of populations (Johnston and Post, 2009). There is evidence that density-dependent compensation and fisheries-induced selection pressure can influence a population's ability to sustain or recover from fishing mortality (Walker, 1998; Cortés, 2007). In a fished population, one might expect an increase in growth rate or a decrease in size at maturity to compensate for higher mortality; however, only a few cases of density-dependent compensation have been empirically described for sharks, and for most species they are poorly understood (Cortés, 1998, 1999, 2007; Walker, 1998). Growth rate has been reported to have increased in juvenile sandbar sharks (C. plumbeus) (Sminkey and Musick, 1995) and Atlantic sharpnose sharks (Rhizoprionodon terraenovae) (Carlson and Baremore, 2003), but no effects have been seen in dusky sharks (C. obscurus) (Natanson et al., 2014) following fisheries-induced decreases in abundance. The uncertainty of the North Atlantic blue shark stock leads to the possibility of the stock being overfished or of overfishing occurring ( $\mathrm{ICCAT}^{2}$ ); therefore, changes in reproductive characteristics were examined. In this study, we did not observe a change in the reproductive characteristics of blue sharks in over 40 years of sampling.

\section{Conclusions}

We reexamined the reproductive characteristics of the blue shark in the Atlantic Ocean. Results of our analysis indicate that the median lengths and weights at maturity did not significantly change from those reported by Pratt (1979). We therefore combined all data from 1971 through 2016 to obtain robust parameter estimates for management. Additionally, the calculated age at maturity also remained the same at 5 years for both sexes.

\section{Acknowledgments}

Thank you to all the participants and officials of shark tournaments over the years as well as cooperating commercial and recreational fishermen for allowing a member of the National Marine Fisheries Service Apex Predators Program to sample their blue sharks. We would like to thank everyone past and present in the Apex Predators Program, especially N. Kohler, R. McBride,
C. McCandless, G. Skomal, and H. Pratt, Jr. We would also like to thank the reviewers, who improved the quality of this manuscript.

\section{Literature cited}

Aasen, $\mathrm{O}$.

1966. Blahaien, Prionace glauca (Linnaeus, 1758). Fisken Havet 1:1-15.

Akaike, $\mathrm{H}$.

1973. Information theory as an extension of the maximum likelihood principle. In Proceedings of the 2nd international symposium on information theory (B. N. Petrov and F. Csaki, eds.), p. 267-281. Akademiai Kiado, Budapest, Hungary.

Bigelow, H. B., and W. C. Schroeder.

1948. Sharks. In Fishes of the western North Atlantic. Part 1: lancelets, cyclostomes, sharks (J. Tee-Van, C. M. Breder, S. F. Hildebrand, A. E. Parr, and W. C. Schroeder, eds.), p. 59-546. Mem. Sears Found. Mar. Res., Yale Univ. Press, New Haven, CT.

Bonfil, R.

1994. Overview of world elasmobranch fisheries. FAO Fish. Tech. Pap. 341, 119 p. FAO, Rome.

Burnham, K. P., and D. R. Anderson.

2002. Model selection and multimodel inference: a practical information-theoretic approach, 2nd ed., 488 p. Springer, New York.

Bustamante, C., and M. B. Bennett.

2013. Insights into the reproductive biology and fisheries of two commercially exploited species, shortfin mako (Isurus oxyrinchus) and blue shark (Prionace glauca), in the southeast Pacific Ocean. Fish. Res. 143:174-183. Crossref

Canty, A., and B. Ripley.

2017. boot: bootstrap R (S-Plus) functions. R package, vers. 1.3-20. [Available from website, accessed July 2017.]

Carlson, J. K., and I. E. Baremore.

2003. Changes in biological parameters of Atlantic sharpnose shark Rhizoprionodon terraenovae in the Gulf of Mexico: evidence for density-dependent growth and maturity? Mar. Freshw. Res. 54:227-234. Crossref

Carrera-Fernández, M., F. Galván-Magaña, and B. P. CeballosVázquez.

2010. Reproductive biology of the blue shark Prionace glauca (Chondrichthyes: Carcharhinidae) off Baja California Sur, México. Aqua Int. J. Ichthyol. 16:101-110.

Castro, J. A., and J. Mejuto.

1995. Reproductive parameters of blue shark, Prionace glauca, and other sharks in the Gulf of Guinea. Mar. Freshw. Res. 46:967-973. Crossref

Castro, J. I.

2011. The sharks of North America, 640 p. Oxford Univ. Press, New York.

Castro, J. I., C. M. Woodley, and R. L. Brudek.

1999. A preliminary evaluation of the status of shark species. FAO Fish. Tech. Pap. 380, 72 p. FAO, Rome.

Clark, E., and K. von Schmidt.

1965. Sharks of the central Gulf coast of Florida. Bull. Mar. Sci. 15:13-83.

Compagno, L. J. V.

1984. FAO species catalogue. Vol. 4. Sharks of the world. An annotated and illustrated catalogue of shark species known to date. Part 2-Carcharhiniformes. FAO Fish. Synop. 125, p. 251-655. FAO, Rome. 
Cortés, E.

1998. Demographic analysis as an aid in shark stock assessment and management. Fish. Res. 39:199-208. Crossref

1999. A stochastic stage-based population model of the sandbar shark in the western North Atlantic. Am. Fish. Soc. Symp. 23:115-136.

2000. Life history patterns and correlations in sharks. Rev. Fish. Sci. 8:299-344. Crossref

2007. Chondrichthyan demographic modelling: an essay on its use, abuse and future. Mar. Freshw. Res. 58:4-6. Crossref

Driggers, W. B., III, J. K. Carlson, B. Cullum, J. M. Dean, D. Oakley, and G. Ulrich.

2004. Age and growth of the blacknose shark, Carcharhinus acronotus, in the western North Atlantic Ocean with comments on regional variation in growth rates. Environ. Biol. Fishes 71:171-178. Crossref

Francis, M. P., and C. Ó. Maolagáin.

2016. Size, maturity and length composition of blue sharks observed in New Zealand tuna longline fisheries. N.Z. Fish. Assess. Rep. 2016/60, 25 p. Minist. Prim. Ind., Wellington, New Zealand. [Available from website.]

Francis, M. P., L. J. Natanson, and S. E. Campana.

2008. The biology and ecology of the porbeagle shark, Lamna nasus. In Sharks of the open ocean: biology, fisheries and conservation (M. D. Camhi, E. K. Pikitch, and E. A. Babcock, eds.) p. 105-113. Blackwell Publ., Oxford, UK.

Gubanov, Y. P., and V. N. Grigor'yev.

1975. Observations on the distribution and biology of the blue shark Prionace glauca (Carcharhinidae) of the Indian Ocean. J. Ichthyol. 15(1):37-43.

Hamlett, W. C.

1999. Male reproductive system. In Sharks, skates, and rays: the biology of elasmobranch fishes (W. C. Hamlett, ed.), p. 444-470. Johns Hopkins Univ. Press, Baltimore, MD.

Hamlett, W. C., and T. J. Koob.

1999. Female reproductive system. In Sharks, skates, and rays: the biology of elasmobranch fishes (W. C. Hamlett, ed.), p. 398-443. Johns Hopkins Univ. Press, Baltimore, MD.

Harry, A. V., A. J. Tobin, and C. A. Simpfendorfer.

2013. Age, growth and reproductive biology of the spot-tail shark, Carcharhinus sorrah, and the Australian blacktip shark, C. tilstoni, from the Great Barrier Reef World Heritage Area, north-eastern Australia. Mar. Freshw. Res. 64:277-293. Crossref

Hazin, F., and R. Lessa.

2005. Synopsis of biological information available on blue shark, Prionace glauca, from the southwestern Atlantic Ocean. Collect. Vol. Sci. Pap. ICCAT 58:1179-1187.

Hilborn, R., and C. J. Walters.

1992. Quantitative fisheries stock assessment: choice, dynamics and uncertainty, 570 p. Chapman and Hall, London.

Izzo, C., and B. M. Gillanders.

2020. Port Jackson shark growth is sensitive to temperature change. Front. Mar. Sci. 7:240. Crossref

Johnston, F. D., and J. R. Post.

2009. Density-dependent life-history compensation of an iteroparous salmonid. Ecol. Appl. 19:449-467. Crossref

Jolly, K. A., C. da Silva, and C. G. Attwood.

2013. Age, growth and reproductive biology of the blue shark Prionace glauca in South African waters. Afr. J. Mar. Sci. 35:99-109. Crossref

Kohler, N. E., and P. A. Turner.

2008. Stock structure of the blue shark (Prionace glauca) in the North Atlantic Ocean based on tagging data.In Sharks of the open ocean: biology, fisheries and conservation (M. D.
Camhi, E. K. Pikitch, and E. A. Babcock, eds.), p. 339-350. Blackwell Publ., Oxford, UK.

2019. Distributions and movements of Atlantic shark species: a 52-year retrospective atlas of mark and recapture data. Mar. Fish. Rev. 81(2):1-93. Crossref

Kohler, N. E., J. G. Casey, and P. A. Turner.

1995. Length-weight relationships for 13 species of shark from the western North Atlantic. Fish. Bull. 93:412-418.

Kohler, N. E., P. A. Turner, J. J. Hoey, L. J. Natanson, and R. Briggs. 2002. Tag and recapture data for three pelagic shark species: blue shark (Prionace glauca), shortfin mako (Isurus xyrinchus), and porbeagle (Lamna nasus) in the North Atlantic Ocean. Collect. Vol. Sci. Pap. ICCAT 54:1231-1260.

Mandelman, J. W., P. W. Cooper, T. B. Werner, and K. M. Lagueux. 2008. Shark bycatch and depredation in the U.S. Atlantic pelagic longline fishery. Rev. Fish Biol. Fish. 18:427. Crossref

McKenzie, R. A., and S. N. Tibbo.

1964. A morphometric description of the blue shark (Prionace glauca) from the Canadian Atlantic waters. J. Fish. Res. Board Can. 21:865-866. Crossref

Megalofonou, P., D. Damalas, and G. de Metrio.

2009. Biological characteristics of blue shark, Prionace glauca, in the Mediterranean Sea. J. Mar. Biol. Assoc. U. K. 89:1233-1242. Crossref

Mejuto, J., and B. García-Cortés.

2005. Reproductive and distribution parameters of the blue shark Prionace glauca, on the basis of on-board observations at sea in the Atlantic, Indian and Pacific Oceans. Collect. Vol. Sci. Pap. ICCAT 58:951-973.

Mejuto, J., B. García-Cortés, and J. M. de la Serna.

2002. Preliminary scientific estimations of by-catches landed by the Spanish surface longline fleet in 1999 in the Atlantic Ocean and Mediterranean Sea. Collect. Vol. Sci. Pap. ICCAT 54:1150-1163.

Nakano, $\mathrm{H}$.

1994. Age, reproduction and migration of blue shark in the North Pacific Ocean. Bull. Natl. Res. Inst. Far Seas Fish. 31:141-256.

Natanson, L. J., and B. J. Gervelis.

2013. The reproductive biology of the common thresher shark in the western North Atlantic Ocean. Trans. Am. Fish. Soc. 142:1546-1562. Crossref

Natanson, L. J., J. J. Mello, and S. E. Campana.

2002. Validated age and growth of the porbeagle shark (Lamna nasus) in the western North Atlantic Ocean. Fish. Bull. 100:266-278.

Natanson, L. J., B. J. Gervelis, M. V. Winton, L. L. Hamady, S. J. B. Gulak, and J. K. Carlson.

2014. Validated age and growth estimates for Carcharhinus obscurus in the northwestern Atlantic Ocean, with preand post-management growth comparisons. Environ. Biol. Fishes 97:881-896. Crossref

Natanson, L. J., M. Winton, H. Bowlby, W. Joyce, B. Deacy, R. Coelho, and D. Rosa.

2020. Updated reproductive parameters for the shortfin mako (Isurus oxyrinchus) in the North Atlantic Ocean with inferences of distribution by sex and reproductive stage. Fish. Bull. 118:21-36. Crossref

NMFS (National Marine Fisheries Service).

1993. Fishery management plan for sharks of the Atlantic Ocean, 167 p. Southeast Reg. Off., Natl. Mar. Fish. Serv., NOAA, St. Petersburg, FL.

2006. Final consolidated Atlantic highly migratory species fishery management plan, 1600 p. Highly Migr. Species Manage. Div., Off. Sustainable Fish., Natl. Mar. Fish. Serv., NOAA, Silver Spring, MD. [Available from website.] 
Pinsky, M. L., R. L. Selden, and Z. J. Kitchel.

2019. Climate-driven shifts in marine species ranges: scaling from organisms to communities. Annu. Rev. Mar. Sci. 12:153-179. Crossref

Pratt, H. L., Jr.

1979. Reproduction in the blue shark, Prionace glauca. Fish. Bull. 77:445-470.

$\mathrm{R}$ Core Team.

2020. R: a language and environment for statistical computing. R Foundation for Statistical Computing, Vienna, Austria. [Available from website, accessed May 2020.]

Skomal, G. B., and L. J. Natanson.

2003. Age and growth of the blue shark (Prionace glauca) in the North Atlantic Ocean. Fish. Bull. 101:627-639.

Sminkey, T. R., and J. A. Musick.

1995. Age and growth of the sandbar shark, Carcharhinus plumbeus, before and after population depletion. Copeia 1994:871-883. Crossref
Vandeperre, F., A. Aires-da-Silva, M. Santos, R. Ferreira, A. B. Bolten, R. S. Santos, and P. Afonso.

2014. Demography and ecology of blue shark (Prionace glauca) in the central North Atlantic. Fish. Res. 153:89-102. Crossref

Veríssimo, A., Í. Sampaio, J. R. McDowell, P. Alexandrino,

G. Mucientes, N. Queiroz, C. da Silva, C. S. Jones, and L. R. Noble. 2017. World without borders-genetic population structure of a highly migratory marine predator, the blue shark (Prionace glauca). Ecol. Evol. 7:4768-4781. Crossref

Walker, T. I.

1998. Can shark resources be harvested sustainably? A question revisited with a review of shark fisheries. Mar. Freshw. Res. 49:553-572. Crossref

Zuur, A. F., E. N. Ieno, and C. S. Elphick.

2010. A protocol for data exploration to avoid common statistical problems. Methods Ecol. Evol. 1:3-14. Crossref 